\title{
Innovations and Tourism Sector's Development in Lankaran Economic District of Azerbaijan in Pandemic Conditions
}

\author{
Samira Huseyn qizi Abasova ${ }^{1^{*}}$ \\ ${ }^{1}$ Economy Institute of Azerbaijan National Academy of Sciences, Baku, Azerbaijan \\ *Email: abasovasamira@rambler.ru
}

\begin{abstract}
Tourism innovations are helping to increase the range of services offered. In the context of the pandemic, innovations have appeared - virtual tours of museums, scenic natural places, hunting and fishing places, gastronomic cuisine of certain cities, etc. The Lankaran economic region of Azerbaijan is one of such attractive places for tourists. Because the Lankaran economic region was a border zone with Iran, it was impossible to come here for foreigners and the residents of Azerbaijan. With the restoration of the sovereignty of Azerbaijan, the Lankaran economic region began to develop its tourism industry, and in 2021, Lankaran became a UNESCO gastronomic city. With this in mind, the author analysed 1) the economic potential and the possibilities of innovative tourism services using in this region, 2) gave an export assessment of external and internal factors which influence the development and improvement of tourism in this area in the context of a pandemic, and 3) identified areas for improving tourism services further.
\end{abstract}

Keywords: Innovations in tourism, Tourism innovations for economic development, Innovation tourism in pandemic conditions, Innovation directions in Azerbaijan tourism sphere, Innovation tourism in the Lankaran economic district in pandemic conditions.

\section{INTRODUCTION}

The COVID-19 pandemic and strict anti-epidemic measures introduced by various countries have accelerated the transformation of world tourism. The industry is losing hundreds of billions of dollars and millions of jobs. By the end of 2020, the international tourism economy will shrink by about $80 \%$, according to the October OECD report "Restoring Tourism for the Future" [1].

It is impossible to improve the economic performance of tourism without the introduction of innovations. In recent years Azerbaijan government has adopted several tourism programmes to develop, improve the traditional types of tourism and create new types of tourism services. Lankaran Regional Tourism Office was opened in 2020. And in 2021, Lankaran city was selected as a world gastronomic city by UNESCO. In this regard, it became necessary to study the tourism potential of Lankaran and the eponymous Lankaran economic region of Azerbaijan [2].

In connection with the pandemic situation, many tourist institutions, hotels and catering establishments of the Lankaran economic region are restructuring their activities, introducing virtual tours to museums, sights, mausoleums, and beautiful types of the environment; ordering e-tickets; introducing protective measures in serving tourists.

\section{RESEARCH METHODOLOGY}

In writing this article, the author has considered some statistical tourism indicators of Azerbaijan and Lankaran economic region during 2015-2020. She has analysed the Azerbaijan tourism sector's innovation potential in pandemic terms.

The author has also considered external and internal factors that influence the tourism industry of Azerbaijan 
and the Lankaran economic region by PEST and SWOT assessment analyses. Abasova S.H. also has used the observation, statistical analysis and research methods in Chapter 3, statistical, research and expert analysing methods in Chapter 4, expert assessment method in research in Chapter 5 of this article.

\section{INNOVATIONS IN THE TOURISM SECTOR}

Geographical and weather conditions, attractions, culture and history, transport and communications, and information technology depend on the growth and promotion of the tourism sector of the national economy. Their maximum use, the combination of different services, the creation of a new product can be the potential for the development of innovative tourism. In the field of implementation of tourism, innovations can be introduced in the sphere of information technology, management and personnel management, and maintenance. In terms of development potentials, the tourism innovations are manifested from radical changes in the tourism sector to improving the management and organisational components of the existing system [3].

The main innovative activities in the tourism market are:

- Implementation of advertising campaigns (through the media);

- Attracting consumers through discounts and promotions and delivering this information to tourists;

- Creation of a positive reputation for potential customers, improvement of service, formation of a system of reviews about tourism companies, hotels and catering subjects;

- Use of information technologies, including the development and creation of convenient means of information searching and delivering, websites, mobile applications, etc.;

- Introduction and promotion of previously unrepresented types of tourism services in the region: new tours, routes, cooperation with air carriers, hotels, restaurants, visiting museums via the Internet and more;

- Construction of new tourist facilities;

- Studying the work of competitors, including successfully developing ones [4].

The main functions of innovation in the tourism industry include the following [5]:

- involvement in the production of new productive forces, increase in labour productivity and efficiency of tourism activity, reduction of various kinds of expenditures;
- each person and society living standard improving as a whole through diversity and quality of the tourism services' provision, meeting the population needs;

- the travel agency structure changing in case of changing needs, maintaining a balance between demand and supply of tourism services, between supply and consumption of tourism services;

- the result of the application of creative capabilities and knowledge of a specific person, human intelligence, which, in turn, stimulates the further growth of creativity in tourism.

Based on the provisions of the Agreement on Trade in Services (GATS) the tourism innovation develops in three areas [6]:

- innovations' introduction (organisational innovations) related to the enterprise and tourism business development;

- marketing innovations that allow to reach the target consumers' needs or attract customers that are not covered for a given time;

- periodic innovations (product innovations) aimed at changing consumer properties for suggested tourism service, its positioning, and providing competitive advantages.

Government supports the tourism innovations by three approaches [7]:

- Allocation of funds for the implementation of targeted programmes in the regions;

- Creation of the information centres' network whose provide their services to travellers free and contribute to enlightening local residents in the field of tourism;

- Financial assistance provision in the form of grants, subsidies, and investments to implement scientific developments with application in the tourism sector and related sectors of the economy [8].

\section{ANALYSE OF TOURISM POTENTIAL OF THE LANKARAN ECONOMIC REGION}

Azerbaijan became a member of the World Tourism Organisation, and the first State Programme on Tourism Development (2002-2005) was successfully implemented [9]. The State Programme for SocioEconomic Development of the Regions is dedicated to constructing up to 35 tourism facilities.

One of the most beautiful parts of our country is the southern region - The development of tourism distinguishes the Lankaran economic region. This economic region has attractive climatic conditions, rich natural resources and unique historical and cultural 
monuments. The Caspian Sea surrounds it from the east and the Talysh range of mountains from the west.

Azerbaijan government has accepted a programme of tourism development for 2025 where the Lankaran economic region reserve the specific place. In 2021 Lankaran city was announced as a UNESCO gastronomic city that will attract European and another country's tourists to this district [10].

It should be noted that the growth of vouchers to the Lankaran economic region in 2018-2019. But with the closure of the borders, the main flow of tourists from Iran could not resume tourist trips to Azerbaijan, which affected the Lankaran economic region's indicators (Table 1).

As can be seen, the best data from the tourism industry was observed in 2019. The pandemic caused by COVID-19 led to many indicators for tourism both in Azerbaijan as a whole and in the Lankaran Economic Region worsened by several dozen times (Table 2). Profit of travel agencies in the Lankaran economic region amounted to -5254.7 thousand AZN loss.

It is a positive fact that many hotels could survive during the pandemic (Tables 2 and 3), even though hotels' profits in the Lankaran economic region decreased by almost 2 times.

Many catering subjects in the Lankaran economic region are private (Table 4). But despite the pandemic of the sanitary and quarantine measures, the catering entities lost their turnover by almost 2 times. But during the pandemic in the Lankaran district were created 26 more catering subjects were created, and an additional 599 service places were created. This is because many entrepreneurs had created (See Table 5 - The volume of investments attracted to tourism facilities in the Lankaran region in 2018-2019) new restaurants and cafes with WHO sanitary standards to meet the growing needs of tourists wishing to visit the gastronomic facilities in the Lankaran region.

\section{ASSESSMENT OF EXTERNAL AND INTERNAL FACTORS THAT INFLUENCE TO INNOVATIVE TOURISM IN THE LANKARAN REGION UNDER PANDEMIC CONDITIONS}

In the state external environment analysing, special attention should be paid to the factors that directly affect the implementation of innovations (Table 6). These:

Table 1. The main tourism indicators of Lankaran economic region in pandemic condition (A Azerbaijan, L - Lankaran economic region) [11-12]

\begin{tabular}{|l|c|c|c|c|c|c|c|c|}
\hline \multirow{2}{*}{ Indicators } & \multicolumn{2}{|c|}{2015} & \multicolumn{2}{c|}{2018} & \multicolumn{2}{c|}{2019} & \multicolumn{2}{c|}{ A } \\
\cline { 2 - 8 } & A & L & A & L & A & L \\
\hline $\begin{array}{l}\text { Number of sold package } \\
\text { tours (number) }\end{array}$ & 44615 & - & 49992 & 452 & 63885 & 631 & 5342 & 247 \\
\hline $\begin{array}{l}\text { Value of sold package } \\
\text { tours (thousand AZN) }\end{array}$ & 33474.7 & - & 66570.7 & 360.0 & 78132.2 & 778.3 & 4988.4 & 114.0 \\
\hline $\begin{array}{l}\text { Total income of travel } \\
\text { agencies and tour } \\
\text { operators (thousand AZN) }\end{array}$ & 36482.2 & - & 56439.4 & 14.5 & 63363.8 & 72.3 & 16147.3 & 29.9 \\
\hline $\begin{array}{l}\text { Total expenditures of } \\
\text { travel agencies and tour } \\
\text { operators (thousand AZN) }\end{array}$ & 30811.6 & - & 46085.1 & 6.5 & 50400.0 & 29.6 & 21899.7 & 21.2 \\
\hline $\begin{array}{l}\text { Total profit of travel } \\
\text { agencies and tour } \\
\text { operators (thousand AZN) }\end{array}$ & 5670.6 & - & 10354.3 & 8.0 & 12963.8 & 42.7 & -5752.4 & 8.7 \\
\hline $\begin{array}{l}\text { Total number of } \\
\text { employees in travel } \\
\text { agencies and tour } \\
\text { operators (person) }\end{array}$ & 1586 & - & 2074 & 2 & 2205 & 4 & 1464 & 4 \\
\hline $\begin{array}{l}\text { Number of tour-days } \\
\text { (person-day) }\end{array}$ & 73262 & 2960 & 100932 & 7958 & 112752 & 12655 & 293 & - \\
\hline
\end{tabular}


Table 2. The main tourism indicators of the Lankaran economic region in the pandemic condition (A Azerbaijan, L - Lankaran economic region) [11-12]

\begin{tabular}{|c|c|c|c|c|c|c|c|c|}
\hline \multirow[t]{2}{*}{ Indicators } & \multicolumn{2}{|c|}{2019} & \multicolumn{2}{|c|}{2020} & \multicolumn{2}{|c|}{$\begin{array}{l}2020 \text { to } 2019, \\
\%\end{array}$} & \multicolumn{2}{|c|}{$\begin{array}{l}\text { Deterioration } \\
\text { several times }\end{array}$} \\
\hline & $A$ & $L$ & $A$ & $L$ & A & L & A & $L$ \\
\hline $\begin{array}{l}\text { Number of sold package tours } \\
\text { (number) }\end{array}$ & 63885.0 & 631.0 & 5342.0 & 247.0 & -91.64 & -60.86 & 11.95 & 2.55 \\
\hline $\begin{array}{l}\text { Value of sold package tours } \\
\text { (thousand AZN) }\end{array}$ & 78132.2 & 778.3 & 4988.4 & 114.0 & -93.62 & -85.36 & 15.66 & 6.82 \\
\hline $\begin{array}{l}\text { Total income of travel } \\
\text { agencies and tour operators } \\
\text { (thousand AZN) }\end{array}$ & 63363.8 & 72.3 & 16147.3 & 29.9 & -74.52 & -58.65 & 3.92 & 2.41 \\
\hline $\begin{array}{l}\text { Total expenditures of travel } \\
\text { agencies and tour operators } \\
\text { (thousand AZN) }\end{array}$ & 50400.0 & 29.6 & 21899.7 & 21.2 & -5.55 & 71.62 & 2.30 & 1.39 \\
\hline $\begin{array}{l}\text { Total profit of travel agencies } \\
\text { and tour operators (thousand } \\
\text { AZN) }\end{array}$ & 12963.8 & 42.7 & -5752.4 & 8.7 & - & -79.63 & -2.25 & 4.90 \\
\hline $\begin{array}{l}\text { Total number of employees in } \\
\text { travel agencies and tour } \\
\text { operators (person) }\end{array}$ & 2205.0 & 4.0 & 1464.0 & 4.0 & $6 ., 39$ & - & 1.50 & 1.00 \\
\hline $\begin{array}{l}\text { Number of tour-days (person- } \\
\text { day) }\end{array}$ & 112752.0 & 12655.0 & 293.0 & - & -99.75 & - & 384.81 & - \\
\hline
\end{tabular}

- actions of the executive authorities to support the tourism development, legislative and regulatory requirements of both national and regional significance, related to tourism;
- the general economic situation under the influence of which consumer demand and the purchasing power of the population are formed;

- intensity and scale of competition [6];

Table 3. The economic indicators of hotels and similar establishments in Azerbaijan (A) and the Lankaran Economic region (L) [11-12]

\begin{tabular}{|l|c|c|c|c|c|c|c|c|}
\hline \multirow{2}{*}{ Indicators } & \multicolumn{2}{|c|}{2015} & \multicolumn{2}{c|}{2019} & \multicolumn{2}{c|}{2020} & \multicolumn{2}{c|}{2020 to 2019, \% } \\
\cline { 2 - 9 } & A & L & A & L & A & L & A & L \\
\hline $\begin{array}{l}\text { Number of hotels and similar } \\
\text { establishments (number) }\end{array}$ & 536 & 68 & 642 & 77 & 655 & 77 & 102.0 & 100.0 \\
\hline $\begin{array}{l}\text { Number of rooms in hotels } \\
\text { (number) }\end{array}$ & 17953 & 31847 & 23865 & 91436 & 24195 & 43052 & 101.4 & 47.0 \\
\hline $\begin{array}{l}\text { Number of accommodation } \\
\text { persons in hotel (thousand } \\
\text { person) }\end{array}$ & 838.2 & 17.0 & 1919.7 & 56.3 & 668.8 & 34.0 & 34.8 & 60.4 \\
\hline $\begin{array}{l}\text { Income of hotels and similar } \\
\text { establishments (million AZN) }\end{array}$ & 183.1 & 2.1 & 45.2 & 6.2 & 116.8 & 3.4 & 258.4 & 54.8 \\
\hline
\end{tabular}


Table 4. Indicators of catering in Azerbaijan (A) and the Lankaran Economic region (L) [11-12]

\begin{tabular}{|l|c|c|c|c|c|c|c|c|}
\hline \multirow{2}{*}{ Indicators } & \multicolumn{2}{|c|}{2015} & \multicolumn{2}{c|}{2019} & \multicolumn{2}{c|}{2020} & \multicolumn{2}{c|}{2020 to 2019, \% } \\
\cline { 2 - 9 } & A & L & A & L & A & L & A & L \\
\hline $\begin{array}{l}\text { Catering turnover (in million } \\
\text { AZN) }\end{array}$ & 1111.2 & 30.2 & 1655.2 & 42.5 & 759.6 & 22.1 & 45.9 & 52.0 \\
\hline -state & 15.2 & & 15.4 & & 5.6 & & & \\
\hline -non-state & 1096.0 & 30.2 & 1639.8 & 42.5 & 754.0 & 22.1 & & 52.0 \\
\hline $\begin{array}{l}\text { Public catering turnover per } \\
\text { capita (AZN) }\end{array}$ & 116.6 & 33.5 & 167.1 & 45.1 & 76.2 & 23.3 & 45.6 & 51.7 \\
\hline $\begin{array}{l}\text { The number of business subjects } \\
\text { engaged in catering activity (unit) }\end{array}$ & 15645 & 912 & 20878 & 1150 & 21483 & 1176 & 102.9 & 102.3 \\
\hline $\begin{array}{l}\text { Number of seats in catering } \\
\text { establishments (unit) }\end{array}$ & 575726 & 20543 & 906527 & 28595 & 934629 & 29194 & 103.1 & 102.1 \\
\hline
\end{tabular}

- the impact of innovation on the socialisation of the people;

- possibilities of communication networks (the possibility of Internet using, other alternative communication methods);

- the possibility of new technologies' using in organising trips (global booking systems by the subjects of the tourism market, the number of companies using new technologies, especially in the regions) [13];

- the time required to promote new computer technologies and new offers in regional markets.

Internet technologies can also be used in the formation of a tourist product for:

1) conducting promotional activities;

2) informing consumers about new products and promotions;

3) the formation of a positive image among tourists visited objects;

4) promotion of new types of tourist services (visiting Internet museums, mountains and forests, reserves of the Lankaran economic region, and Azerbaijan).
In particular, it should be noted that recently the latter service has become widespread and is interesting for many target groups, in particular for schoolchildren, who, while conducting lessons using the Internet, can visit the museums, geographical areas that can be located in another country and get acquainted with the achievements of world culture and art [5].

Advertising and social networks (Booking, B2B, TripAdvisor, Agoda, etc.) play an important role in promoting. For example, TripAdvisor is the world's largest travel review platform and has more than 450 million users and more than 570 million reviews. According to a study by PhoCusWright, $70 \%$ of travellers read customer rating notes on TripAdvisor before choosing a hotel, and $53 \%$ of travellers do not book any tour without reading reviews [16].

For these reasons, hotels' and restaurants' top managers in the Lankaran economic region must do their best to ensure the ideal form of services. The best way to advertise is to respond politely to assertive comments written online, not negatively affecting customers. This situation in Azerbaijan is not so heartening because most of the customers do not comment in the "comments"

Table 5. The volume of investments attracted to tourism facilities in the Lankaran econnomic region in 2018-2019, million AZN [11-12]

\begin{tabular}{|l|c|c|}
\hline & 2018 & 2019 \\
\hline Engineering investments in the Lankaran economic region & 100 & 150 \\
\hline Investments to repair work in the Lankaran economic region & 79 & 80 \\
\hline
\end{tabular}


section of the hotel's website, whether they are satisfied with the hotel or not.

Although Azerbaijan lags behind some countries in terms of tourism opportunities and tourist reception, it surpasses many countries (India, Arabia and China) in terms of friendly staff, cleanliness and cuisine.
According to COVID-19 and the protocol covering the rules of hygiene, the symptoms of employees are identified and removed from the client. A social distance plan has been developed between hotel and catering staff and customers.

Table 6. PEST assessment analysis on the development of innovative tourism in the Lankaran region [14-15]

\begin{tabular}{|c|c|}
\hline Positive assessment & Negative assessment \\
\hline \multicolumn{2}{|c|}{ Political factors } \\
\hline $\begin{array}{l}\text { Cabinet of Ministers' Order related to the } \\
\text { tourism facilities' licensing; } \\
\text { tourism facilities by Lankaran economic region's } \\
\text { Culture and Tourism Office; } \\
>\quad \text { The organisation of various festivals and } \\
\text { events at the state level }\end{array}$ & $\begin{array}{l}>\quad \text { Lankaran economic region's travel agencies' } \\
\text { indifference to obtaining a license; }\end{array}$ \\
\hline \multicolumn{2}{|c|}{ Economical factors } \\
\hline $\begin{array}{l}\text { well-known in the USSR the Istisu sanatorium's } \\
\text { reengineering, which to help restore the } \\
\text { musculoskeletal system; } \\
\text { recreation areas' modernisation; } \\
\text { the construction of } 5^{*} \text { hotels; } \\
\text { modern requirements in the Lankaran economic } \\
\text { region. }\end{array}$ & $\begin{array}{l}>\text { Many hotels do not have a } 5^{*} \text { mark; } \\
\text { Few rooms for } 1 \text { and } 3 \text { people in hotels; } \\
>\quad \text { Lack of certified } 3^{*} \text { and } 4^{*} \text { hotels; } \\
\text { regulations in catering establishments specialising in } \\
\text { national cuisine; } \\
>\text { Defects in water supply and sewerage } \\
\text { structure. }\end{array}$ \\
\hline \multicolumn{2}{|c|}{ Social factors } \\
\hline $\begin{array}{l}\text { Application of training for tourism facilities' } \\
\text { employees; } \\
\text { women employees like managers in the tourism } \\
\text { sphere; } \\
\text { the region and their participation in the tourism sector. }\end{array}$ & $\begin{array}{l}>\text { Lack of knowledge of foreign languages by } \\
\text { employees of tourism facilities (Persian, Arabic, English); } \\
\text { hotels and restaurants; } \\
>\text { Non-involvement of women in top managerial } \\
\text { positions; } \\
>\text { Staff's sluggishness in hotels. }\end{array}$ \\
\hline \multicolumn{2}{|c|}{ Technological factors } \\
\hline $\begin{array}{l}>\text { Implementation of digital startups in the } \\
\text { sphere of travel tech, } \\
>\quad \text { the emergence of new opportunities for } \\
\text { individual virtual tours; } \\
>\quad \text { formats of international cooperation using } \\
\text { information technologies. }\end{array}$ & $\begin{array}{l}\text { Non-compliance of Lankaran city port and } \\
\text { bridge to modern requirements; } \\
\text { virtual video tours of mountainous, coastal and forest } \\
\text { landscapes; } \\
\text { Bureaucratic obstacles in the formation of } \\
\text { technology workers. }\end{array}$ \\
\hline
\end{tabular}


The guests' temperature is measured with thermal chambers or non-contact temperature gauges. The guests' shoes are cleaned with disinfectant mats at the entrance to the hotel and restaurant. The customer's hands are wiped with alcohol or another cleaning agent. Each guest is given an individual mask and gloves.

Social distance rules are expected in all common areas (dining halls, reception rooms, animation areas, bars, dance halls, sales departments, outdoor seating, waiting rooms, beach tents, sunbeds), and warning signs are placed in these areas. Sections such as children's playrooms, children's clubs, amusement parks, playgrounds are not used within the enterprise. Lifts can be entered with a mask and no more than 4 people.

There are 1.5 metres between dining tables and $60 \mathrm{sm}$ between chairs. SPA units such as baths, saunas, massage services are not available in establishments without a Healthy Tourism Certificate [17].

Towels for the beach pool are provided by employees on duty in sealed bags for use by guests.
Client rooms, surfaces in the rooms and telephone, remote control, water heater, door and window handles and furniture and equipment in the room are disinfected after leaving the room. Filters for air conditioning and ventilation systems are changed frequently. If possible, the hotel charges a non-contact fee. Staff always use masks and gloves.

During the research, the author noted some shortcomings in the Lankaran eoonomic region related to tourism. These include high prices for tourism services, incompetent staff, poor control over the rented houses by government agencies, expensive service prices that do not meet the requirements of $3 *$ and $4 *$ hotels and so on. Tourists usually prefer to walk mainly when travelling, so there is no need for $5^{*}$ hotels to spend the night. For this reason, the number of low-star, cheap hotels and hostels should be increased, and the service level should be raised.

In addition, the sanitary control of rented houses by government agencies should be once a week. The

Table 7. SWOT analysis of the introduction of innovative tourism services in Azerbaijan and in the Lankaran economic region [11-12], [14-15]

\begin{tabular}{|c|c|}
\hline S (strength) & W (weaknesses) \\
\hline $\begin{array}{l}\text { Availability of developed economic and } \\
\text { cultural, international relations in tourism; } \\
\text { international } \\
\text { field of tourism; } \\
\text { projects and programmes, including in the } \\
\text { implementility of a tourism development } \\
\text { imperation in Lankaran economic region. }\end{array}$ & $\begin{array}{l}\text { lack of investment resources; } \\
\text { the objects of historical and cultural heritage (many } \\
\text { objects cannot be included in the system of excursion } \\
\text { display and online viewing in advertising); } \\
\text { standards; } \\
\text { ansatisfactory of tourism products in international } \\
\text { analytical information in the field of tourism. }\end{array}$ \\
\hline (opportunities/perspectives) & T (threats) \\
\hline $\begin{array}{l}\text { widespread use the cross-border tourism; } \\
\text { ecological, mountain, sport, water, as well as cultural } \\
\text { and business tourism; } \\
\text { programmes for tourism specialists based on leading } \\
\text { educational Azerbaijan universities; } \\
>\quad \text { implementation of state support and } \\
\text { information accessibility of tourism in Azerbaijan; } \\
>\quad \text { development of tourism infrastructure to } \\
\text { implement international projects and attract } \\
\text { investments in the tourism sphere. }\end{array}$ & $\begin{array}{l}>\text { the imperfection of the regulatory and legal } \\
\text { framework for tourism; } \\
\text { tourism services, even domestic tourism; } \\
>\text { tougher competition for tourist flows in the } \\
\text { region among travel agencies; } \\
>\text { threatening growth of tourists from Arab } \\
\text { countries. }\end{array}$ \\
\hline
\end{tabular}


hygienic cleanliness of roadside restaurants and cafes should be checked frequently.

At present, there are more than 16 hotels and 5 resorts operating in Lankaran city. There are also rented cottages for tourists. However, the quality of tourism services, safety (fire, insurance, etc.) and sanitation in these rented hotels are deficient. In these hotels, the customers' birthdays are celebrated with special pomp. Customers often turn to this innovative tourism service (Table 7 SWOT analysis of the introduction of innovative tourism services in Azerbaijan and in the Lankaran economic region).

Like other innovative tourism services are:

1) the rooms are equipped in the national style,

2) historical museum corners are created, and each banquet hall is decorated on different themes. For example, the Khan Lankaran Hotel in Lankaran city offers high-quality restaurants and hospitality to tourists and a museum that preserves and promotes the national heritage of Azerbaijan. Restaurants, hotel rooms, courtyards and meeting rooms in the hotel are created and decorated in the national style (carpets, rugs, cupboards and lamas, copper pots, trays, jugs, etc.), dolls in national style ("Arshin mal alan" film's heroes, puppets in national costumes, women and children, statues of horses and donkeys, flower baskets and Novruz holiday kings, etc.) and offer services of interest to tourists, as well as a wide range of opportunities for photoshoots;

3) special trips for tourists. Hotels in the Lankaran economic region offer trips to the Hirkan forest and Lake Ambulan, as well as the Yanar spring (where could see the flames of fire in the water), excursions to the Lankaran khan's palace, which was built in the 19th century in the European style, fishing and other routes.

\section{CONCLUSION}

According to the author, the application of innovative tourism services in the Lankaran economic region is necessary:

1. Support for the construction of the Lankaran city cargo terminal to improve the transport and road system, the port of Lankaran city and the bridge to bring ships closer to shore in Lankaran city;

2. Implement specific measures to increase employment from the current tourism potential of the region. These include preserving old folk art, improving folk craftsmanship and employment improving either new project creating for development of carpet weaving;

3. Implementation of the programme on promotion of folk art and carpet weaving for the development of the protection of ancient folk arts in the Yardimli district;
4. Support the construction of a "Land of Longevity" in Lerik district, which is considered a tourism zone and recreation centre for 50 people to increase the prospects for tourism development;

5. Development of projects for the formation of mountain tourism in Lankaran economic region;

6. Beautiful places of Lankaran economic region's Talysh mountains, black sandy beaches, citrus tea plantations, pyramids, Hirkan forest, reserves, etc. making video tours and ensuring their sale as an Internet service;

7. Formation and application of e-ticket portal for 1 and 2-day bus travel;

8. Implementation of innovations in information technology;

9. Implementation of support programmes to improve the skills and competencies of tourism subjects' employees in the region.

\section{REFERENCES}

[1] E. Katkova, How the coronavirus changes world tourism indusrtry [Kak koronavirus menyaet mirovuyu turindustriyu] / Vedomosti, December 3, 2020. Retrieved from: https://www.vedomosti.ru/partner/articles/2020/12/ 20/851707-antivirus-puteshestvii

[2] Passport of the Lankaran Economic Region Lənkəran iqtisadi rayonun passport. Retrieved from: http:// www.http://ier.az-

[3] I.I. Tikhomirova, A.A. Andreeva, Innovative activities in the field of tourism: Essence and specificity [Innovacionnaya deyatel'nost' $\mathrm{v}$ sfere turizma: sushchnost' i specifika] // Internet magazine "Sciences" [Internet-zhurnal «Naukovedenie»], Volume 7, No. 2, 2015. Retrieved from: http://naukovedenie.ru/PDF/102EVN215.pdf. DOI: https://doi.org/10.15862/102EVN215

[4] The use of innovation in the tourism [Primenenie innovacij $\mathrm{V}$ sfere turizma]. Retrieved from: https://viafuture.ru/katalog-idej/innovatsii-vturizme

[5] Innovative technology in tourism [Innovacionnye tekhnologii $\mathrm{v}$ turizme]. Retrieved from: http://tourfaq.net (03.11.2015).

[6] M.M. Zueva, Innovation Activities as a means of strengthening the economic potential of the tourism industry [Innovacionnaya deyatel'nost' kak sredstvo ukrepleniya ekonomicheskogo potenciala industrii turizma] / Management of economic systems [Upravlenie ekonomicheskimi sistemami], No. 
5(41), 2012. Retrieved from: https://tourlib.net/statti_tourism/zueva2.htm

[7] M.V. Kalitvintseva, Main directions of innovation activities in tourism [Osnovnye napravleniya innovacionnoj deyatel'nosti $\mathrm{v}$ turizme] / Scientific works Sworld [Nauchnye trudy Sworld] 11(3) (2011) 81-85. Retrieved from: https://tourlib.net/statti_tourism/kalitvinceva3.htm

[8] S.V. Valeeva, The importance of innovative update in tourism for the national economy in new realities [Znachenie innovacionnogo obnovleniya $\mathrm{v}$ sfere turizma dlya nacional'noj ekonomiki v svete novyh realij] // National interests: priorities and safety [Nacional'nye interesy: prioritety i bezopasnost'] 21(306) (2015) 44-56. Retrieved from: https://cyberleninka.ru/article/n/znachenieinnovatsionnogo-obnovleniya-v-sfere-turizmadlya-natsionalnoy-ekonomiki-v-svete-novyh-realiy

[9] Social and economic development of the regions [Social'no-ekonomicheskoe razvitie regionov] Baku, Goskomstat 1-12 (2019) 36.

[10] Azerbaijan National Culinary Center has achieved another success (Azərbaycan Milli Kulinariya Mərkəzi növbəti uğura imza atıb - 08.12.2021). Retrieved from: https://azertag.az/xeber/Azerbaycan_Milli_Kulinari ya_Merkezi_novbeti_ugura_imza_atib-1945928

[11] Lankaran economic district, Azerbaijan Republic State Statistical Committee date, 2020. Retrieved from: https://www.stat.gov.az/source/regions/

[12] Tourism in Azerbaijan, Baku, Azerbaijan Republic State Statistical Committee, 2021, 99p. Retrieved from: https://www.stat.gov.az/source/tourism/

[13] B. Zhanzakov, The development of tourist services and factors influencing tourism competitiveness [Razvitie turisticheskih uslug i faktory vliyayushchie na konkurentosposobnost' turizma]. Conference Materials Conference "Lomonosov 2020" [Materialy konferencii Konferenciya «Lomonosov 2020»]. DOI: https://doi.org/10.13140/RG.2.2.34994.22724

Retrieved from: https://www.researchgate.net/publication/3435475 $\underline{61}$

[14] S.H. Abasova, Analysis of Health Tourism Activity and its Development in Azerbaijan, Science and practice in solving the strategic and tactical problems of sustainable development of Russia "International Scientific and Practical Conference, St. Petersburg Centre for System Analysis [Nauka i praktika $\mathrm{v}$ reshenii strategicheskih i takticheskih zadach ustojchivogo razvitiya Rossii" mezhdunarodnaya nauchno-prakticheskaya konferenciya, Sankt-Peterburskij Centr Sistemnogo Analiza], Russia, 30.01.2019-31.01, 2019, 250 p.

[15] S.H. Abasova, Complex analysis of tourist services in Azerbaijan and its innovative development [Kompleksnyj analiz turisticheskih uslug v Azerbajdzhane i ego innovacionnoe razvitie], World Science 1-8(36) (2018) 61-68. DOI: https://doi.org/10.31435/rsglobal_ws/30082018/60 56 Retrieved from: https://cyberleninka.ru/article/n/kompleksnyyanaliz-turisticheskih-uslug-v-azerbaydzhane-i-egoinnovatsionnoe-razvitie

[16] The place of tourism in the economy - Turizmin iqtisadiyyatdak1 yeri. Retrieved from: http://www.tursab.org.tr

[17] Pandemic and tourism: the global economy can lose more than $\$ 4$ trillion [Pandemiya i turizm: global'naya ekonomika mozhet lishit'sya bolee 4 trln dollarov]. Retrieved from: https://news.un.org/ru/story/2021/06/1405562 